\title{
Recent Advances in the Role of Natural Killer Cells in Acute Kidney Injury
}

\section{Claudia Cantoni ${ }^{1,2}$, Simona Granata ${ }^{3}$, Maurizio Bruschi ${ }^{4}$, Grazia Maria Spaggiari ${ }^{2}$, Giovanni Candiano ${ }^{4}$ and Gianluigi Zaza ${ }^{3 *}$}

${ }^{1}$ Laboratory of Clinical and Experimental Immunology, Integrated Department of Services and Laboratories, IRCCS Istituto Giannina Gaslini, Genoa, Italy, ${ }^{2}$ Department of Experimental Medicine (DIMES) and Center of Excellence for Biomedical Research (CEBR), University of Genoa, Genoa, Italy, ${ }^{3}$ Renal Unit, Department of Medicine, University-Hospital of Verona, Verona, Italy, ${ }^{4}$ Laboratory of Molecular Nephrology, IRCCS Istituto Giannina Gaslini, Genoa, Italy

Growing evidence is revealing a central role for natural killer (NK) cells, cytotoxic cells belonging to the broad family of innate lymphoid cells (ILCs), in acute and chronic forms of renal disease. NK cell effector functions include both the recognition and elimination of virus-infected and tumor cells and the capability of sensing pathogens through Toll-like receptor (TLR) engagement. Notably, they also display immune regulatory properties, exerted thanks to their ability to secrete cytokines/chemokines and to establish interactions with different innate and adaptive immune cells. Therefore, because of their multiple functions, NK cells may have a major pathogenic role in acute kidney injury (AKI), and a better understanding of the molecular mechanisms driving NK cell activation in $\mathrm{AKI}$ and their downstream interactions with intrinsic renal cells and infiltrating immune cells could help to identify new potential biomarkers and to select clinically valuable novel therapeutic targets. In this review, we discuss the current literature regarding the potential involvement of NK cells in AKI.

Keywords: inflammation, natural killer (NK) cells, tubular epithelial cells, acute kidney injury, innate immunity

\section{INTRODUCTION}

Acute kidney injury (AKI) is a life-threatening multifactorial clinical condition leading to a rapid deterioration of the renal function associated with high morbidity, mortality (ranging from 25\% to more than $50 \%$ depending on severity), and healthcare costs. In a large number of patients, AKI may be followed by irreversible and progressive chronic kidney damage (1-3).

Recent efforts have been made to standardize definitions and classification systems for AKI, and in 2004, the Acute Dialysis Quality Initiative first proposed the Risk, Injury, Failure, Loss, and EndStage Renal Disease (RIFLE) criteria for diagnosis and classification of acute impairments in kidney function, which included five stages ranging from small changes in kidney function or urine output to kidney failure and end-stage renal disease (4). These criteria were subsequently refined into a three-stage system and further disseminated by the Acute Kidney Disease Network in $2007(5,6)$. In 2012, the KDIGO Clinical Practice Guideline for AKI consolidated these criteria into the most recent definition and classification system for AKI (7). The current definition and classification of AKI rely upon functional criteria including changes in serum creatinine $(\mathrm{SCr})$ and urine output $(6,8-10)$. However, despite the harmonization in clinical definition and staging, identification of the complete biology and pathophysiology of AKI remains a major unmet need. 
To this purpose, several research strategies have been undertaken to identify new cellular/biological elements implicated in the AKI-derived organ damage networking. Among them, the immune-inflammatory deregulation in this condition has been emphasized. As largely reported, the activation of immune-mediated mechanisms in AKI patients is a common thread, with immune cells playing a prominent role from initiating injury to promoting tissue repair $(11,12)$.

Renal epithelial cells, just after the acute offense, increase the expression of damage-associated molecular pattern (DAMP) molecules, Toll-like receptors (TLRs), and other alarmins (1317) that, all together, facilitate a rapid recruitment to the site of injury of innate immune cells, including neutrophils, activated and resident macrophages, and dendritic cells (DCs) (18-21). Furthermore, in the last years, natural killer (NK) cells, extravasated from the vascular system to the site of injury, have been shown to play a role in the propagation of the immune response and the recruitment of adaptive immune cells (22-24).

In this review, we focus on NK cell populations found in the kidney, and we discuss their role in the induction and progression of AKI.

\section{NATURAL KILLER CELLS}

NK cells are cytotoxic cells belonging to the broad family of innate lymphoid cells (ILCs) (25-28). Their effector functions range from the recognition and elimination of virus-infected and tumor cells to the secretion of cytokines/chemokines; importantly, they also display immune regulatory properties, exerted through interactions with different innate, and adaptive immune cells (29-31). In addition, they display the capability of sensing pathogens through TLR engagement and also to develop a kind of immunological memory (32-34). In order to exert these heterogeneous functions, NK cells use a large array of receptors able to sense stimuli from the microenvironment and, consequently, to mediate appropriate responses (35-37).

The recognition and elimination of abnormal cells can be fulfilled through receptor-ligand interactions involving several inhibitory and activating receptors and different types of ligands expressed on target cells. NK cells express multiple inhibitory surface receptors involved in the interaction with major histocompatibility complex (MHC) class I molecules and responsible for the "missing-self" recognition. The "missingself hypothesis," formulated by Ljunggren and Kärre (38) in the early 90s, postulated that NK cells can detect the absence of self MHC class I molecules on target cells. In humans, human leukocyte antigen (HLA) class I molecules expressed on autologous healthy cells allow the delivery of a negative signal, thus sparing normal cells from NK cellmediated killing. On the other hand, virus-infected or tumor cells can lose or downregulate HLA class I expression, and the lack or dampening of the inhibitory interaction makes them susceptible to an NK cell-mediated attack. The main HLA class I-specific inhibitory NK cell receptors include killer immunoglobulin (Ig)-like receptors (KIR), leukocyte Ig-like receptor, subfamily $\mathrm{B}$ member 1 (LIR1)/Ig-like transcript 2
(ILT2), and the cluster of differentiation 94 (CD94)/NK group 2 member A (NKG2A) heterodimer. Collectively, they can recognize different HLA-A, -B, -C alleles, and non-classical HLA-E molecules, representing an efficient system to detect alterations in HLA class I expression (39-43). Later on, it was shown that recognition and killing of target cells by NK lymphocytes requires additional signals, mainly delivered by activating receptors $(37,44-47)$.

Besides CD16 (FcyRIII), representing the first characterized activating NK cell receptor and responsible for antibodydependent cell-mediated cytotoxicity (ADCC), a variety of surface receptors and co-receptors, involved in the so-called natural cytotoxicity, were discovered over the years. The receptors playing a major role in the recognition of abnormal cells are represented by natural cytotoxicity receptors (NCRs, namely, NKp46, NKp30, and NKp44), NKG2D, and DNAX accessory molecule 1 (DNAM-1) (45, 48-55). While the ligands specific for NKG2D and DNAM-1 were identified long time ago and have been extensively characterized, ligands recognized by NCR started to be defined later, and the knowledge about NCR-ligand interactions is still incomplete $(49,56-61)$.

The best characterized ligands for activating NK receptors include molecules that are scarcely expressed on healthy/normal cells and that can be induced or upregulated following cellular stress, neoplastic transformation, and/or viral infection $(52,53$, 55, 62-65). While many of these ligands are surface-expressed molecules, also nuclear proteins have been shown to bind to activating $\mathrm{NK}$ receptors following translocation to the target cell surface $(66,67)$. More recently, the landscape of NK cell receptor ligands has become even more heterogeneous in view of the finding that some NK cell receptors can also bind to secreted soluble factors, circulating molecules belonging to the complement system, or extracellular matrix components (68-70).

Given the multiplicity of receptor-ligand interactions, the engagement of NK cell receptors by specific ligands can result in opposite signals dictating the outcome of NK cell-mediated effector functions. NK cells can also respond to cytokines, including interleukin (IL)-12, IL-15, and IL-18 (mainly produced by myeloid cells upon inflammatory stimuli), and, in turn, release cytokines and chemokines, such as tumor necrosis factor (TNF)- $\alpha$, interferon (IFN)- $\gamma$, granulocyte-macrophage colonystimulating factor (GM-CSF), and CC-chemokine ligand 4 (CCL4) $(30,31,71,72)$.

Finally, the immunoregulatory role of NK cells has been deeply explored, starting from the characterization of NKDC cross-talk (73-75). In this context, NK cells participate both in DC maturation and in the "DC editing" process through the recognition and killing of immature DCs that lack appropriate levels of MHC class I molecules. On the other hand, DC can favor NK cell proliferation and effector functions (76). More recently, the relevance of NK cells in immune regulation was further investigated, demonstrating the ability of NK cells to establish interactions also with other innate immune cells, i.e., macrophages and granulocytes, as well as with $\mathrm{T}$ lymphocytes (77-81). 


\section{HETEROGENEITY OF NATURAL KILLER CELLS}

A further level of complexity arises from the heterogeneity of NK cells, i.e., the existence of different NK cell subsets characterized by distinct phenotypic and functional features and from their different localizations in the body $(30,72,82,83)$.

\section{Human Natural Killer Cells}

In humans, NK cells were initially divided into two populations based on the expression of CD56 and CD16 surface markers (84). CD56 ${ }^{\text {bright }} \mathrm{CD} 16^{\mathrm{dim} / \mathrm{neg}} \mathrm{NK}$ cells usually express the inhibitory HLA-E-specific receptor CD94/NKG2A but not KIR and low or undetectable CD16; they are poorly cytotoxic, being characterized by low intracellular levels of perforin and granzymes $\mathrm{A}$ and $\mathrm{B}$, but can secrete high amounts of cytokines (primarily IFN- $\gamma$ and TNF- $\alpha$ ) in response to IL-2, IL-12, IL-15, and IL-18 $(85,86)$. According to their expression of chemokine and homing receptors (i.e., CCR7, CXCR3, CXCR4, and CD62L), CD56 $6^{\text {bright }} \mathrm{NK}$ cells are mainly found in secondary lymphoid organs (SLOs), particularly in lymph nodes and tonsils, and also constitute a detectable fraction of NK cells in different organs and tissues (87). On the other hand, the CD56 ${ }^{\text {dim }} \mathrm{CD} 16^{\text {pos }}$ $\mathrm{NK}$ cell population is the predominant subset in peripheral blood, expresses NKG2A and/or KIR, and displays a high cytolytic potential and cytokine secretion capability following recognition of target cells expressing ligands for triggering NK receptors (88-90). Besides being more abundant in peripheral blood, the CD56 ${ }^{\mathrm{dim}}$ subset represents a remarkable fraction of NK cells found in spleen, bone marrow, and in certain nonlymphoid organs, such as lungs and kidney. CD56 ${ }^{\text {dim }}$ NK cells can be further classified in different subsets based on distinct differentiation stages, the terminally differentiated one being represented by a KIR ${ }^{\text {pos }} \mathrm{CD} 57^{\text {pos }} \mathrm{CD} 16^{\text {bright }}$ subset which may express the activating HLA-E-specific receptor CD94/NKG2C (30, 91-96).

In addition, in recent years, it has also been discovered that, similar to adaptive $\mathrm{T}$ lymphocytes, also NK cells can undergo a process of clonal-like expansion and develop a kind of immunological memory. This concept was initially explored in the context of cytomegalovirus (CMV) infection, which was shown to modify the composition of the total NK cell repertoire and to drive a clonal-like expansion of given NK subsets $(32,97-100)$. In humans, these "memory" NK cells are distinguished by the expression of self HLA class I-binding KIRs, the terminal differentiation marker CD57, and the activating receptor complex CD94/NKG2C (101-103).

Finally, in the last decade, tissue-resident NK (trNK) cells were characterized as an additional NK cell population, resembling CD56 ${ }^{\text {bright }} \mathrm{NK}$ cells populating secondary lymphoid tissues but displaying markers of tissue residency/retention and mainly localized in non-lymphoid tissues (104-108). In view of these findings, the "traditional" CD56 $6^{\text {dim }}$ and CD56 $6^{\text {bright }} \mathrm{NK}$ cell subsets, mediating a potent cellular cytotoxicity and able to produce IFN- $\gamma$, are often defined as conventional NK (cNK) cells.

The discovery of tissue residency markers, such as CD69, CD49a ( $\alpha 1$ integrin), and CD103 ( $\alpha$ E integrin), was essential for the characterization of these trNK cells. CD69, which for a long time has been considered an activation marker for $\mathrm{T}$ and $\mathrm{NK}$ cells, plays an important role in retaining cells in tissues, thus representing a marker of local residency, both in humans and in mice (109-111). In particular, CD69 inhibits sphingosine-1 phosphate receptor 1 (SIP1), specific for sphingosine-1 phosphate (SIP), which normally promotes the egress of lymphocytes from tissues into the blood. NK cells localized in different tissues have been shown to express CD69, while cNK cells derived from peripheral blood generally do not express this marker. CD103 and CD49a play a similar role in retaining cells in tissues, and their expression is induced by transforming growth factor- $\beta$ (TGF- $\beta$ ) (112). Indeed, CD69, CD103, and CD49a markers allow to distinguish trNK cells from circulating $\mathrm{cNK}$ cells that are transiently recruited into tissues. Another possible mechanism related to tissue retention involves chemokines and chemokine receptors. While trCD56 $6^{\text {bright }} \mathrm{NK}$ cells found in lymphoid organs and liver are characterized by CXCR6 and CCR5 expression, circulating CD56 $6^{\text {bright }} \mathrm{NK}$ cells mainly express CCR7 (24, 107, 113).

\section{Murine Natural Killer Cells}

In mice, NK cells are phenotypically characterized by the expression of several surface markers including CD161 (NK1.1), NKp46, the family of MHC class I-specific Ly49 receptors, and CD49b ( $\alpha 2$ integrin, DX5) $(35,42,114-118)$. While circulating cNK cells are defined as NKp46 ${ }^{+} \mathrm{CD}_{49} \mathrm{a}^{-} \mathrm{CD} 49 \mathrm{~b}^{+}$, trNK cells display an $\mathrm{NKp}^{+} 6^{+} \mathrm{CD}_{49 \mathrm{a}^{+}} \mathrm{CD} 49 \mathrm{~b}^{-}$phenotype $(108,119)$. Similar to human NK cells, cNK cell maturation in the mouse is a stepwise process, characterized by four stages according to CD11b and CD27 expressions $(120,121)$, with terminally mature NK cells being $\mathrm{CD}_{2} 7^{-} \mathrm{CD} 11 \mathrm{~b}^{+}$and also expressing KLRG1. Recent studies based on single-cell RNA-sequencing approaches have provided a more detailed view of murine NK cell developmental stages $(122,123)$. Five subsets have been identified on the basis of different genetic signatures, including the least mature NK and most mature NK clusters and three clusters defined as transitional NK subsets, which may represent intermediate steps of maturation or unique NK subsets that diverge late during development.

\section{NATURAL KILLER CELLS AND INNATE LYMPHOID CELLS}

NK cells are not the only innate lymphocytes, being included in the family of innate lymphoid cells (ILCs) that are involved in homeostatic functions and in innate immune responses against different classes of pathogens $(27,28,124,125)$.

While cytokine release is a common feature of all ILCs, NK cells are the only cytotoxic cells among the ILCs. Initially, ILCs were divided into three main groups according to the expression of key transcription factors and distinct cytokine profiles. More recently, a greater heterogeneity of ILCs was appreciated, and these cells have been consequently classified into five subsets (NK cells, ILC1, ILC2, ILC3, and LTi cells) based on their development and function (27). NK cells share some features with ILC1, 
being characterized by the expression of T-bet transcription factor and the production of type I cytokines, such as IFN- $\gamma$ and TNF- $\alpha$. NK cells are the main ILCs found in peripheral blood, spleen, and bone marrow, whereas non-NK ILCs are more abundant in other secondary lymphoid tissues, including mucosa-associated lymphoid tissue (MALT) $(126,127)$. Notably, co-expression of T-bet and Eomesodermin (Eomes) transcription factors, besides cytotoxic potential, discriminates NK cells from ILC1. A further degree of complexity exists among ILC1 in relation to the heterogeneous expression of several markers. For instance, while ILC1 had been originally described as $\mathrm{CD}_{56}^{-}$, the expression of CD56 can identify a subgroup of tonsil and intraepithelial ILC1 (ieILC1) characterized by cytotoxic granule expression and the ability to produce IFN- $\gamma(125,128,129)$. In addition, CD56 can also be expressed by a subset of ILC3 $(125,130)$. ILC2 express GATA binding protein 3 (GATA3) transcription factor, display the ability to produce T helper type 2 (TH2)-like cytokines (i.e., IL-4, IL-5, and IL-13), and are tissueresident. ILC3 are characterized by retinoic acid receptor-related orphan nuclear receptor gamma (ROR- $\gamma \mathrm{t}$ ) expression, produce TH17-like cytokines, and are abundant in the mucosae; based on the expression of NKp44 in humans (and of NKp46 in mice), they can be further divided into two subsets (131). LTi cells share with ILC3 the expression of ROR- $\gamma$ t transcription factor, but they have a distinct developmental path and are involved in the formation of secondary lymphoid structures (132). Since tissue residency is a general hallmark of ILCs, it has to be considered that some old studies analyzing NK cells in tissues should actually be reevaluated in view of recent findings concerning ILCs.

As for other organs, the presence of ILCs has been investigated in the kidney, revealing that group 2 ILCs represent the prevalent ILC population, both in mice and in humans, and can be expanded and activated by the epithelial cell-derived cytokines IL-25 or IL-33 (133-136). Notably, these cells can exert a protective effect in AKI through the induction of alternatively activated (M2) macrophages.

\section{NATURAL KILLER CELLS IN THE KIDNEY}

The high heterogeneity of NK cells became more evident especially when their tissue localization was analyzed in different body compartments. It is now well-established that NK cells are found not only as circulating cells in peripheral blood, where they represent about $5-15 \%$ of lymphocytes, but also in SLOs as well as in different organs and tissues, in which specific NK cell subsets have been characterized $(87,105,137)$.

NK cell trafficking from blood to tissues or lymphoid organs is coordinated by chemokines and their respective receptors, dictating the migration of different NK cell subsets to given compartments or to inflammatory sites (22-24). Notably, depending on the organ or tissue, NK cells can exhibit unique phenotypic characteristics and develop specific functional properties. trNK cells exhibit differences in terms of trafficking and tissue retention. Interestingly, trNK cells residing in different districts share some common features but also peculiar properties that might reflect the influence of the local microenvironment in shaping these cells $(104-106,108,119)$. The body districts with the highest prevalence of NK cells are the liver (137-144), lungs (145-147), and uterus (148-151). NK cells have also been found in several other organs including the kidney, intestinal mucosa, breast tissue, synovia, pleural and peritoneal fluids, skin, salivary glands, and adipose tissue (105, 137, 152-154). Notably, the relative distribution of CD56 $6^{\text {bright }}$ and CD56 $6^{\text {dim }}$ NK cell subsets is heterogeneous in different tissues; while in most cases, CD56 ${ }^{\text {bright }}$ perforin ${ }^{\text {low }}$ cells (non-cytotoxic) represent the prevalent subset, the lungs contain a higher proportion of CD56 $^{\mathrm{dim}}$ perforin ${ }^{\text {high }} \mathrm{NK}$ cells, and the kidney is populated by intermediate levels of these two NK cell populations.

NK cells represent about $25 \%$ of lymphocytes in the healthy human kidney, with an enrichment in the CD56 $6^{\text {bright }} \mathrm{NK}$ cell subset as compared with peripheral blood (137, 155-157). Until recently, however, information on tissue-resident lymphocyte populations, and in particular on trNK cells in the kidney, had been relatively limited. Although the presence of both innate and adaptive lymphocytes in this district was known for a long time, it was not clear whether these cells displayed features of tissue residency, similar to what was previously observed in other organs and tissues. In recent years, several studies helped to clarify this issue both in mice and in humans. In this context, parabiosis experiments performed in mouse models proved to be very effective in demonstrating the presence of trNK cells in the kidney.

The study by Victorino et al. in the mouse showed that about $15-20 \%$ of NK cells in the kidney are represented by a tissueresident $\mathrm{CD} 49 \mathrm{a}^{+} \mathrm{DX} 5^{-} \mathrm{NK}$ cell population reminiscent of trNK cells harbored in other organs, such as the liver and uterus (158). The discrimination between trNK cells and ILC1 residing in non-lymphoid tissues is crucial, in view of the similarities between these two cell populations, including the CD49a ${ }^{+} \mathrm{DX} 5^{-}$ phenotype. Studies performed in different tissues allowed to establish that most murine ILC1 are $\mathrm{CD} 127^{+}\left(\mathrm{IL}-7 \mathrm{R} \alpha^{+}\right)$and do not express the Eomes transcription factor, while murine trNK cells are $\mathrm{CD}_{127}^{-}$and depend on Eomes for their development. In addition, CD200R1 surface marker has been associated with ILC1 but not with NK cells $(27,127,159,160)$. Finally, trNK cells display some cytotoxic capability thanks to the expression, albeit at low/moderate levels, of perforin and granzymes, whereas ILC1 (except for ieILC1) are non-cytotoxic cells. Although not all these markers have been analyzed so far in renal NK cells, it is conceivable that trNK cells in the kidney may share several markers with trNK cells that have been better characterized in other tissues.

The murine kidney also harbors a substantial number of $\mathrm{CD}_{49} \mathrm{a}^{-} \mathrm{DX}^{+} \mathrm{NK}$ cells that are considered $\mathrm{cNK}$ cells passing through the organ. Contrary to cNK cells, kidney trNK cells do not require NFIL3 and Tbet transcription factors for their development and express lower levels of Asialo-GM1 (AsGM1) as compared to $\mathrm{CD} 49 \mathrm{a}^{-} \mathrm{DX} 5^{+} \mathrm{cNK}$ cells; this finding suggests that NK cell depletion by anti-AsGM1 antibodies could be incomplete/inefficient and gives the possibility to investigate trNK cell function in animal models. Indeed, selective (by antiAsGM1 mAb) or total (by anti-NK1.1 mAb) depletion of NK cells 
allowed to assess the predominant role of trNK cells in a model of ischemic AKI (see below).

In addition, NK cells residing in the kidney are very efficient in producing IFN- $\gamma$, and this property has been shown to play an important role in progressive tubule-interstitial fibrosis and chronic kidney disease (CKD) (155). IFN- $\gamma$ can induce the production of profibrotic factors, such as transglutaminase 2 (TG2) and the heparan sulfate proteoglycan syndecan-4 (sdc4) that contribute to the accumulation of extracellular matrix, thus favoring the development of renal fibrosis. This issue has been recently explored in a murine model of aristolochic acid nephropathy (AAN), in which the presence of trNK cells positively correlated with the progression of tubule-interstitial fibrosis (161).

Also in humans, healthy kidney harbors a relevant NK cell compartment: NK cells represent approximately 25\% of total lymphocytes; both CD56 $6^{\text {bright }}$ and CD56 ${ }^{\text {dim }}$ NK cells can be found, with a higher proportion of CD56 ${ }^{\text {bright }} \mathrm{NK}$ cells in the kidney (about $37 \%$ of total NK cells) as compared to peripheral blood (>10\%) (137). Interestingly, a recent study, analyzing kidney biopsies from patients with different renal diseases, revealed the existence of a CD56 $6^{\text {bright }} \mathrm{NK}$ cell population with tissue residency features (CD69 expression) and the ability to release IFN- $\gamma$ (155).

\section{NATURAL KILLER CELLS IN ACUTE KIDNEY INJURY}

AKI is a clinical condition characterized by acute impairment of kidney function and induced by different causes, including ischemia, sepsis, and toxic insults $(1,162-164)$. In particular, ischemia-reperfusion injury (IRI) is one of the most frequent events leading to severe AKI.

A common hallmark of severe AKI is the occurrence of acute tubular necrosis. In the kidney, different parenchymal cells, including tubular epithelial cells (TECs) and endothelial cells, can respond to DAMPs or to pathogen-associated molecular patterns (PAMPs) through several TLRs and/or inflammasome components and thus contribute to renal inflammation. Indeed, several DAMPs, released as a consequence of tissue damage, or PAMPs expressed by infectious agents, can activate not only innate immune cells but also non-immune cells. Several studies concerning the role of TECs in kidney injury confirmed an active role for these cells both in the induction and in the regulation of inflammatory responses $(13-17,165,166)$.

The expression of TLR2 and TLR4 on TECs allows these cells to sense endogenous inducers of inflammation and subsequently to be activated to produce several cytokines and chemokines (167). In particular, TLR2 involvement has been assessed in kidney IRI, where hypoxic conditions can induce tubular necrosis and the consequent release of endogenous TLR ligands, which will act at both autocrine and paracrine levels (i.e., on endothelial cells and on innate immune cells) $(13,16,168,169)$. DAMPs are also recognized by renal DCs, which contribute to the inflammatory response and to neutrophil recruitment by the secretion of inflammatory mediators, cytokines, and chemokines.
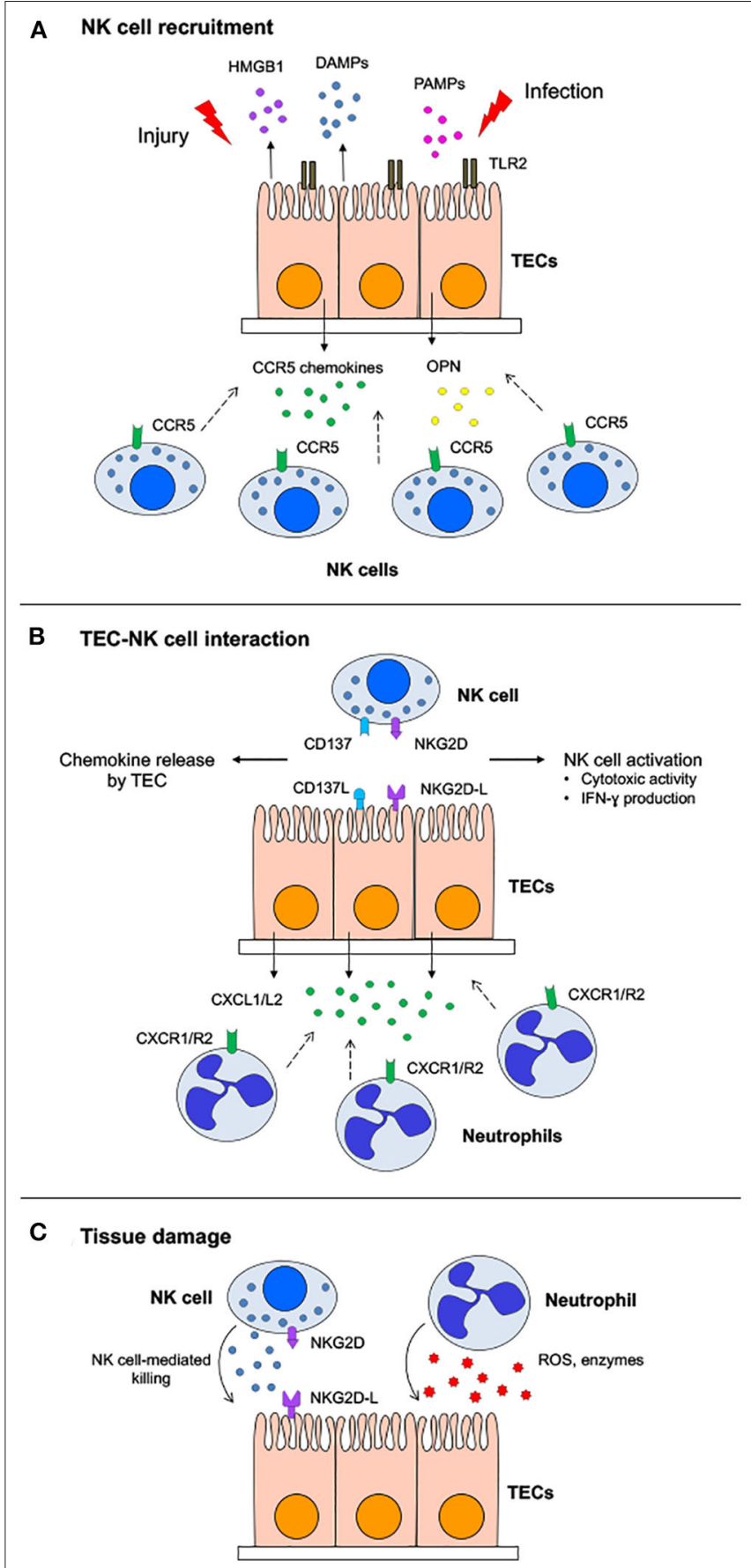

FIGURE 1 | Role of natural killer (NK) cells in acute kidney injury. (A) Following acute kidney injury, damage-associated molecular patterns (DAMPs) released by damaged tubular epithelial cells (TECS) or pathogen-associated molecular patterns (PAMPs) derived from infectious agents are recognized by pattern recognition receptors expressed on TECs that in turn release osteopontin (OPN) and CCR5 chemokines able to recruit NK cells. (B) TEC-NK cell cross-talk occurs through different receptor-ligand pairs. NKG2D ligands (NKG2D-L), upregulated on TECs, engage NKG2D on NK cells, inducing both cytotoxic activity and interferon (IFN)- $\gamma$ production. On the other hand, CD137-CD137L interaction stimulates in TECs the secretion of chemokines attracting neutrophils. (C) TECs are killed by NK cells through the release of cytotoxic granules, while activated neutrophils are responsible for tissue damage due to reactive oxygen species (ROS) and lytic enzymes. 


\section{Tubular Epithelial Cell-Natural Killer Cell Interactions}

Of particular interest is the interplay occurring between NK cells and TECs in the context of kidney injury, especially in view of the finding that NK cells are recruited in the earliest stages of IRI, already $4 \mathrm{~h}$ after injury (Figure 1) (170). The injured TECs release high-mobility group box protein 1 (HMGB1), an endogenous TLR2 ligand released following tissue damage that stimulates CCR5 chemokine production through TLR2 in an autocrine manner. CCR5 chemokines (CCL3, CCL4, and CCL5) in turn mediate recruitment of NK cells that induce TEC to release CXCL1 and CXCL2 chemokines, responsible for the accumulation of neutrophils in the kidney (169). Overall, TECs play a critical role in the induction and orchestration of acute renal inflammation by regulating the sequential migration of NK cells and neutrophils into the kidney during the early phase of IRI.

The involvement of NK cells in IRI was further supported by the finding that, in mice, the expression of ligands for the activating receptor NKG2D (Rae-1, MULT-1, and H60), is increased during kidney IRI and is paralleled by a concomitant rapid NK cell infiltration in injured kidney (171-173). This seems mediated by HMGB1 through engagement of TLR4 and subsequent MyD88-dependent signaling (174). The role of TLR4 was further confirmed by in vitro experiments showing RAE-1 and MULT-1 upregulation on isolated TECs following lipopolysaccharide (LPS) exposure (173).

Both in murine and human TECs, the expression of ligands specific for activating NK cell receptors has been demonstrated, suggesting that these receptor-ligand interactions could be involved in the recognition and killing of TECs. Thus, activated spleen-derived murine NK cells were shown to efficiently kill syngeneic TECs in vitro mainly through the engagement of NKG2D activating receptor by Rae-1 ligand expressed on TECs and by the use of perforin (172).

Similarly to what was observed in murine models, human NK cells display the in vitro ability to kill TECs (HK-2 cell line) exposed to hypoxia, a condition mimicking ischemic AKI, following the interaction of NKG2D receptors with MHC class I chain-related protein A (MICA), whose expression is upregulated in human TECs by hypoxia-inducible factor-1 alpha (HIF-1 $\alpha$ ) transcription factor (175). One possible mechanism of MICA upregulation in hypoxic conditions involves TGF- $\beta$, a cytokine playing multifunctional roles in inflammation, injury, and tissue repair and induced in the kidney and in TECs, following ischemic injury $(176,177)$. It is of note, however, that TGF- $\beta$ expression has been shown to correlate with limitation of renal IRI, better TEC survival, and protection against NK cell-mediated killing $(177,178)$.

These effects can be explained by the fact that TGF- $\beta$, besides increasing MICA surface expression on TECs, also induces higher levels of soluble MICA, a well-known mechanism of modulation of NK cell-mediated cytotoxic activity (62, 179). In addition, TGF- $\beta$ exerts a regulatory role on NK cell function mainly through the downregulation of different activating receptors, including NKG2D and NKp30 $(180,181)$. In view of these findings, the modulation of surface and soluble MICA expression could represent a useful strategy to reduce renal injury.

Although the mechanisms responsible for NK cell recruitment and activation in renal IRI have not been fully elucidated, a role for osteopontin (OPN) has been demonstrated. OPN is a secreted glycoprotein expressed in different immune cells, including NK cells, and exerting pro-inflammatory functions (182-184). Notably, mRNA and protein OPN expression is increased in the kidney shortly after IRI (185-187), and OPN has been shown to promote ischemic kidney injury $(186,187)$.

The role of OPN, however, is still debated since a protective effect for OPN both in kidney IRI and in tissue repair was reported (188). Interestingly, it has been shown that TECs display the ability to secrete high levels of OPN, which in turn can induce a rapid NK cell migration with an indirect, still undefined, mechanism, possibly involving the induction of chemokines or other chemotactic factors able to recruit NK cells. In addition,

TABLE 1 | NK cell populations described in human and murine kidney.

Human NK cells

\begin{tabular}{|c|c|c|}
\hline Phenotype & Main observations & References \\
\hline \multicolumn{3}{|l|}{ Murine NK cells } \\
\hline Phenotype & Main observations & References \\
\hline $\mathrm{CD} 45^{\mathrm{pos}} \mathrm{CD} 3^{\text {neg }} \mathrm{NK} 1.1^{\text {pos }}$ & NK cells involved in kidney IRI & (191) \\
\hline 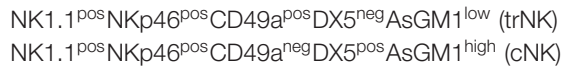 & $\begin{array}{l}\text { CNK and trNK cells described in the kidney } \\
\text { trNK cells involved in kidney IRI }\end{array}$ & $(158)$ \\
\hline $\begin{array}{l}C D 3^{\text {neg }} N K p 46^{\text {pos }} D X 5^{\text {neg }}(\text { trNK }) \\
C D 3^{\text {neg }} N K p 46^{\text {pos }} D X 5^{\text {pos }}(\mathrm{cNK})\end{array}$ & $\begin{array}{l}\text { trNK cells involved in tubulointerstitial fibrosis } \\
\text { trNK cells: accumulation in fibrotic tissue and IFN- } \gamma \text { production }\end{array}$ & (161) \\
\hline
\end{tabular}

NK, natural killer; IRI, ischemia-reperfusion injury; cNK, conventional NK cells; trNK, tissue-resident NK cells; AsGM1, Asialo-GM1; IFN- $\gamma$, interferon- $\gamma$. 
OPN can activate NK cells and increase their cytotoxic activity against primary TECs (187).

More recently, the involvement of OPN in renal injury following ischemia-reperfusion was further validated by Cen et al. in an in vivo model. This study confirmed an OPN increase following IRI, both at the mRNA and protein levels, and demonstrated that neutralization of OPN by an antiOPN mAb resulted in a decreased NK cell infiltration in the kidney associated with a reduced severity of renal injury, lower levels of pro-inflammatory cytokines, and decreased neutrophil infiltration (189). Interestingly, high OPN expression was also observed in kidney grafts, and chronic transplant kidney injury was abrogated in OPN-deficient kidney grafts after transplantation, suggesting that OPN could play a role also in kidney allograft injury (190).

The search for additional TEC-NK cell interactions involved in renal IRI led to the characterization of the co-stimulatory CD137-CD137 ligand (CD137L) axis. Previously, several reports had already pointed to a role for CD137-CD137L interaction in inflammation. CD137L expressed on professional APC can co-stimulate TH1 helper $\mathrm{T}$ cells through the engagement of CD137; on the other hand, reverse signaling induced on APC can promote cytokine and chemokine secretion.

In the context of renal IRI, CD137 expression on activated NK cells results in the transmission of a "reverse signal" on TECs through the binding to CD137L; in turn, TECs produce high levels of CXC chemokines, such as CXCL1 and CXCL2, responsible for neutrophil recruitment and the subsequent acute inflammatory response (191).

Indeed, in a mouse model of acute IRI, the expression of CD137 on NK cells and CD137L on TECs was required for kidney injury. In addition, NK cell depletion experiments demonstrated the essential role of NK cells in neutrophil recruitment and the resulting renal injury. Depletion of neutrophils abrogated renal IRI as well, suggesting that neutrophils were directly responsible for tissue damage associated with renal IRI, while NK cells were responsible for neutrophil recruitment. In this context, it is of note that NK cells can be rapidly recruited in the kidney, within $4 \mathrm{~h}$ after IRI, and upregulate CD137 surface expression, suggesting their important role in the first phases of acute tissue damage.

The role of trNK cells as central mediators of ischemic tissue injury was clearly demonstrated in a model of ischemic AKI (158). The analysis of both cNK and trNK cells at 4 and $24 \mathrm{~h}$ after reperfusion revealed that IRI did not modify either the relative distribution or the original phenotype of these two cell subsets. Notably, trNK cells were characterized by a higher expression of several markers, including CD160, CD44, and TRAIL, suggestive of a higher activation state, and by lower levels of KLRG1 and CD244 inhibitory receptors. Based on their tissue residency and activation state, trNK cells can exert a prominent role in the

\section{REFERENCES}

1. Bonventre JV, Yang L. Cellular pathophysiology of ischemic acute kidney injury. J Clin Invest. (2011) 121:4210-21. doi: 10.1172/JCI45161 early local response during IRI; it is conceivable that cNK cells recruited into the tissue can further enhance tissue damage.

IRI is an inevitable event associated with kidney transplantation. Being actively involved in the induction of inflammatory responses, TECs play a major role in this process $(13,17,168,192)$. Moreover, in kidney transplant rejection, TECs represent one of the major targets of the alloreactive immune response mediated by $\mathrm{CD} 8^{+} \mathrm{T}$ lymphocytes and NK cells. The study by Demmers et al. analyzed the in vitro susceptibility of primary donor-derived TECs activated by IFN- $\gamma$ and TNF- $\alpha$ to CTL- and NK cell-mediated killing. While unstimulated allogeneic TECs were efficiently killed by both $\mathrm{CD}^{+} \mathrm{T}$ cells and NK cells of the recipient, cytokine-activated TECs became more resistant to NK cell-mediated killing presumably because of the increased expression levels of HLA class I molecules. This study also evaluated the effect of different immunosuppressive drugs on immune-mediated TEC lysis, showing their limited efficacy in vitro and differential inhibitory effects on CTL vs. NK cells (193).

\section{CONCLUDING REMARKS}

In recent years, the knowledge about blood-derived and tissueresident NK cells found in the kidney is improved, revealing once again the complexity and the versatility of this ILC population (Table 1). In this context, the role of NK cells has also been addressed in immune-mediated pathologic conditions affecting the kidney. For instance, it is now clear that NK cells are involved in the pathogenesis of AKI, as demonstrated both in animal models and in humans. In particular, the role of NK cells in AKI can occur by distinct mechanisms, including (i) NK cell recruitment and activation mediated by CCR 5 chemokines (directly) or OPN (indirectly) secreted by TECs; (ii) secretion of neutrophil-attracting chemokines induced in TECs through the CD137-CD137L axis; iii) NK cell-mediated killing of TECs through NKG2D-NKG2D-L interactions.

Therefore, because of their major involvement in AKI pathogenesis, NK cells could represent a novel target for future strategies for this important clinical condition.

\section{AUTHOR CONTRIBUTIONS}

CC and GZ wrote the manuscript. SG, MB, GS, and GC reviewed the manuscript and provided critical input. All authors listed have made a substantial, direct and intellectual contribution to the work, and approved it for publication.

\section{FUNDING}

This work was supported by the following grants: Compagnia di San Paolo (ID ROL 20729) (CC, GS, and GC); funds from Renal Child Foundation (MB and GC). 
4. Bellomo R, Ronco C, Kellum JA, Mehta RL, Palevsky P, ADQI Work Group. Acute dialysis quality initiative, acute renal failure - definition, outcome measures, animal models, fluid therapy and information technology needs: the second international consensus conference of the acute dialysis quality initiative (ADQI) group. Crit Care. (2004) 8:R204-12. doi: 10.1186/cc2872

5. Mehta RL, Kellum JA, Shah SV, Molitoris BA, Ronco C, Warnock DG. Acute kidney injury, acute kidney injury network: report of an initiative to improve outcomes in acute kidney injury. Crit Care. (2007) 11:R31. doi: 10.1186/cc5713

6. Barry R, James MT. Guidelines for classification of acute kidney diseases and disorders. Nephron. (2015) 131:221-6. doi: 10.1159/000441425

7. Kellum JA, Lameire N, Aspelin P, Barsoum RS, Burdmann EA, Goldstein SL, et al. Kidney Disease: improving global outcomes (KDIGO) acute kidney injury work group. KDIGO Clinical practice guideline for acute kidney injury. Kidney Int. (2012) 2:1-138. doi: 10.1038/kisup.2012.1

8. Palevsky PM, Liu KD, Brophy PD, Chawla LS, Parikh CR, Thakar CV, et al. KDOQI US commentary on the 2012 KDIGO clinical practice guideline for acute kidney injury. Am J Kidney Dis. (2013) 61:64972. doi: 10.1053/j.ajkd.2013.02.349

9. James M, Bouchard J, Ho J, Klarenbach S, LaFrance JP, Rigatto C, et al. Canadian society of nephrology commentary on the 2012 KDIGO clinical practice guideline for acute kidney injury. Am J Kidney Dis. (2013) 61:67385. doi: 10.1053/j.ajkd.2013.02.350

10. Jha V, Kumar V. Acute kidney injury: validating the KDIGO definition and staging-one step at a time. Nat Rev Nephrol. (2014) 10:5501. doi: 10.1038/nrneph.2014.160

11. Kurts C, Panzer U, Anders HJ, Rees AJ. The immune system and kidney disease: basic concepts and clinical implications. Nat Rev Immunol. (2013) 13:738-53. doi: $10.1038 /$ nri3523

12. Jang HR, Rabb H. Immune cells in experimental acute kidney injury. Nat Rev Nephrol. (2015) 11:88-101. doi: 10.1038/nrneph.2014.180

13. Leemans JC, Stokman G, Claessen N, Rouschop KM, Teske GJ, Kirschning CJ, et al. Renal-associated TLR2 mediates ischemia/reperfusion injury in the kidney. J Clin Invest. (2005) 115:2894-903. doi: 10.1172/JCI22832

14. Wu H, Chen G, Wyburn KR, Yin J, Bertolino P, Eris JM, et al. TLR4 activation mediates kidney ischemia/reperfusion injury. J Clin Invest. (2007) 117:2847-59. doi: 10.1172/JCI31008

15. Anders HJ. Toll-like receptors and danger signaling in kidney injury. J Am Soc Nephrol. (2010) 21:1270-4. doi: 10.1681/ASN.2010030233

16. Rosin DL, Okusa MD. Dangers within: DAMP responses to damage and cell death in kidney disease. J Am Soc Nephrol. (2011) 22:41625. doi: 10.1681/ASN.2010040430

17. Allam R, Scherbaum CR, Darisipudi MN, Mulay SR, Hagele H, Lichtnekert $\mathrm{J}$, et al. Histones from dying renal cells aggravate kidney injury via TLR2 and TLR4. J Am Soc Nephrol. (2012) 23:1375-88. doi: 10.1681/ASN.2011111077

18. Rabb H, O’Meara YM, Maderna P, Coleman P, Brady HR. Leukocytes, cell adhesion molecules and ischemic acute renal failure. Kidney Int. (1997) 51:1463-8. doi: 10.1038/ki.1997.200

19. Li L, Huang L, Sung SS, Vergis AL, Rosin DL, Rose CE Jr, et al. The chemokine receptors CCR2 and CX3CR1 mediate monocyte/macrophage trafficking in kidney ischemia-reperfusion injury. Kidney Int. (2008) 74:1526-37. doi: 10.1038/ki.2008.500

20. Jang HR, Rabb H. The innate immune response in ischemic acute kidney injury. Clin Immunol. (2009) 130:41-50. doi: 10.1016/j.clim.2008.08.016

21. Lee S, Huen S, Nishio H, Nishio S, Lee HK, Choi BS, et al. Distinct macrophage phenotypes contribute to kidney injury and repair. J Am Soc Nephrol. (2011) 22:317-26. doi: 10.1681/ASN.2009060615

22. Gregoire C, Chasson L, Luci C, Tomasello E, Geissmann F, Vivier E, et al. The trafficking of natural killer cells. Immunol Rev. (2007) 220:16982. doi: 10.1111/j.1600-065X.2007.00563.x

23. Maghazachi AA. Role of chemokines in the biology of natural killer cells. Curr Top Microbiol Immunol. (2010) 341:37-58. doi: 10.1007/82_2010_20

24. Castriconi R, Carrega P, Dondero A, Bellora F, Casu B, Regis S, et al. Molecular mechanisms directing migration and retention of natural killer cells in human tissues. Front Immunol. (2018) 9:2324. doi: 10.3389/fimmu.2018.02324

25. Artis D, Spits H. The biology of innate lymphoid cells. Nature. (2015) 517:293-301. doi: 10.1038/nature14189
26. Diefenbach A, Colonna M, Romagnani C. The ILC world revisited Immunity. (2017) 46:327-32. doi: 10.1016/j.immuni.2017.03.008

27. Vivier E, Artis D, Colonna M, Diefenbach A, Di Santo JP, Eberl G, et al. Innate lymphoid cells: 10 years on. Cell. (2018) 174:105466. doi: 10.1016/j.cell.2018.07.017

28. Vacca P, Munari E, Tumino N, Moretta F, Pietra G, Vitale M, et al. Human natural killer cells and other innate lymphoid cells in cancer: friends or foes? Immunol Lett. (2018) 201:14-19. doi: 10.1016/j.imlet.2018.11.004

29. Trinchieri G. Biology of natural killer cells. Adv Immunol. (1989) 47:187376. doi: 10.1016/S0065-2776(08)60664-1

30. Caligiuri MA. Human natural killer cells. Blood. (2008) 112:4619. doi: 10.1182/blood-2007-09-077438

31. Vivier E, Raulet DH, Moretta A, Caligiuri MA, Zitvogel L, Lanier LL, et al. Innate or adaptive immunity? The example of natural killer cells. Science. (2011) 331:44-9. doi: 10.1126/science.1198687

32. Sun JC, Beilke JN, Lanier LL. Adaptive immune features of natural killer cells. Nature. (2009) 457:557-61. doi: 10.1038/nature07665

33. Cooper MA, Yokoyama WM. Memory-like responses of natural killer cells. Immunol Rev. (2010) 235:297-305. doi: 10.1111/j.0105-2896.2010.00891.x

34. Muntasell A, Vilches C, Angulo A, Lopez-Botet M. Adaptive reconfiguration of the human NK-cell compartment in response to cytomegalovirus: a different perspective of the host-pathogen interaction. Eur J Immunol. (2013) 43:1133-41. doi: 10.1002/eji.201243117

35. Vivier E, Tomasello E, Baratin M, Walzer T, Ugolini S. Functions of natural killer cells. Nat Immunol. (2008) 9:503-10. doi: 10.1038/ni1582

36. Moretta L, Pietra G, Montaldo E, Vacca P, Pende D, Falco M, et al. Human NK cells: from surface receptors to the therapy of leukemias and solid tumors. Front Immunol. (2014) 5:87. doi: 10.3389/fimmu.2014. 00087

37. Sivori S, Carlomagno S, Pesce S, Moretta A, Vitale M, Marcenaro E. TLR/NCR/KIR: which one to use and when? Front Immunol. (2014) 5:105. doi: 10.3389/fimmu.2014.00105

38. Ljunggren $\mathrm{HG}$, Kärre $\mathrm{K}$. In search of the 'missing self': MHC molecules and NK cell recognition. Immunol Today. (1990) 11:237-44. doi: 10.1016/0167-5699(90)90097-S

39. Moretta A, Bottino C, Vitale M, Pende D, Biassoni R, Mingari MC, et al. Receptors for HLA class-I molecules in human natural killer cells. Annu Rev Immunol. (1996) 14:619-48. doi: 10.1146/annurev.immunol.14.1.619

40. Long EO, Burshtyn DN, Clark WP, Peruzzi M, Rajagopalan S, Rojo $S$, et al. Killer cell inhibitory receptors: diversity, specificity, and function. Immunol Rev. (1997) 155:135-44. doi: 10.1111/j.1600-065X.1997. tb00946.x

41. Colonna M. Specificity and function of immunoglobulin superfamily NK cell inhibitory and stimulatory receptors. Immunol Rev. (1997) 155:12733. doi: 10.1111/j.1600-065X.1997.tb00945.x

42. Lanier LL. Natural killer cells: from no receptors to too many. Immunity. (1997) 6:371-8. doi: 10.1016/S1074-7613(00)80280-0

43. Parham P. MHC class I molecules and KIRs in human history, health and survival. Nat Rev Immunol. (2005) 5:201-14. doi: 10.1038/nri1570

44. Lopez-Botet M, Llano M, Navarro F, Bellon T. NK cell recognition of non-classical HLA class I molecules. Semin Immunol. (2000) 12:10919. doi: $10.1006 / \mathrm{smim} .2000 .0213$

45. Moretta A, Bottino C, Vitale M, Pende D, Cantoni C, Mingari $\mathrm{MC}$, et al. Activating receptors and coreceptors involved in human natural killer cell-mediated cytolysis. Annu Rev Immunol. (2001) 19:197223. doi: 10.1146/annurev.immunol.19.1.197

46. Lanier LL. Up on the tightrope: natural killer cell activation and inhibition. Nat Immunol. (2008) 9:495-502. doi: 10.1038/ni1581

47. Long EO, Kim HS, Liu D, Peterson ME, Rajagopalan S Controlling natural killer cell responses: integration of signals for activation and inhibition. Annu Rev Immunol. (2013) 31:227-58. doi: 10.1146/annurev-immunol-020711-075005

48. Hudspeth K, Silva-Santos B, Mavilio D. Natural cytotoxicity receptors: broader expression patterns and functions in innate and adaptive immune cells. Front Immunol. (2013) 4:69. doi: 10.3389/fimmu.2013.00069

49. Barrow AD, Martin CJ, Colonna M. The natural cytotoxicity receptors in health and disease. Front Immunol. (2019) 10:909. doi: 10.3389/fimmu.2019.00909 
50. Bauer S, Groh V, Wu J, Steinle A, Phillips JH, Lanier LL, et al. Activation of NK cells and T cells by NKG2D, a receptor for stress-inducible MICA. Science. (1999) 285:727-9. doi: 10.1126/science.285.5428.727

51. Cerwenka A, Lanier LL. Ligands for natural killer cell receptors: redundancy or specificity. Immunol Rev. (2001) 181:15869. doi: 10.1034/j.1600-065X.2001.1810113.x

52. Raulet DH, Gasser S, Gowen BG, Deng W, Jung H. Regulation of ligands for the NKG2D activating receptor. Annu Rev Immunol. (2013) 31:41341. doi: 10.1146/annurev-immunol-032712-095951

53. El-Gazzar A, Groh V, Spies T. Immunobiology and conflicting roles of the human NKG2D lymphocyte receptor and its ligands in cancer. J Immunol. (2013) 191:1509-15. doi: 10.4049/jimmunol.1301071

54. Shibuya A, Campbell D, Hannum C, Yssel H, Franz-Bacon K, McClanahan T, et al. DNAM-1, a novel adhesion molecule involved in the cytolytic function of $\mathrm{T}$ lymphocytes. Immunity. (1996) 4:573-81. doi: 10.1016/S1074-7613(00)70060-4

55. Bottino C, Castriconi R, Pende D, Rivera P, Nanni M, Carnemolla B, et al. Identification of PVR (CD155) and Nectin-2 (CD112) as cell surface ligands for the human DNAM-1 (CD226) activating molecule. J Exp Med. (2003) 198:557-67. doi: 10.1084/jem.20030788

56. Bottino C, Castriconi R, Moretta L, Moretta A. Cellular ligands of activating NK receptors. Trends Immunol. (2005) 26:221-6. doi: 10.1016/j.it.2005.02.007

57. Koch J, Steinle A, Watzl C, Mandelboim O. Activating natural cytotoxicity receptors of natural killer cells in cancer and infection. Trends Immunol. (2013) 34:182-91. doi: 10.1016/j.it.2013.01.003

58. Lam RA, Chwee JY, Le Bert N, Sauer M, von Strandmann EP, Gasser S. Regulation of self-ligands for activating natural killer cell receptors. Ann Med. (2013) 45:384-94. doi: 10.3109/07853890.2013.792495

59. Kruse PH, Matta J, Ugolini S, Vivier E. Natural cytotoxicity receptors and their ligands. Immunol Cell Biol. (2014) 92:221-9. doi: 10.1038/icb.2013.98

60. Horton NC, Mathew PA. NKp44 and natural cytotoxicity receptors as damage-associated molecular pattern recognition receptors. Front Immunol. (2015) 6:31. doi: 10.3389/fimmu.2015.00031

61. Parodi M, Favoreel H, Candiano G, Gaggero S, Sivori S, Mingari MC, et al. NKp44-NKp44 ligand interactions in the regulation of natural killer cells and other innate lymphoid cells in humans. Front Immunol. (2019) 10:719. doi: 10.3389/fimmu.2019.00719

62. Groh V, Bahram S, Bauer S, Herman A, Beauchamp M, Spies T. Cell stressregulated human major histocompatibility complex class I gene expressed in gastrointestinal epithelium. Proc Natl Acad Sci U S A. (1996) 93:1244550. doi: 10.1073/pnas.93.22.12445

63. Cosman D, Mullberg J, Sutherland CL, Chin W, Armitage R, Fanslow $\mathrm{W}$, et al. ULBPs, novel MHC class I-related molecules, bind to CMV glycoprotein UL16 and stimulate NK cytotoxicity through the NKG2D receptor. Immunity. (2001) 14:123-33. doi: 10.1016/S1074-7613(01)00095-4

64. Brandt CS, Baratin M, Yi EC, Kennedy J, Gao Z, Fox B, et al. The B7 family member B7-H6 is a tumor cell ligand for the activating natural killer cell receptor NKp30 in humans. J Exp Med. (2009) 206:1495503. doi: 10.1084/jem.20090681

65. Baychelier F, Sennepin A, Ermonval M, Dorgham K, Debre P, Vieillard V. Identification of a cellular ligand for the natural cytotoxicity receptor NKp44. Blood. (2013) 122:2935-42. doi: 10.1182/blood-2013-03-489054

66. von Strandmann EP, Simhadri VR, von Tresckow B, Sasse S, Reiners KS, Hansen HP, et al. Human leukocyte antigen-B-associated transcript 3 is released from tumor cells and engages the NKp30 receptor on natural killer cells. Immunity. (2007) 27:965-74. doi: 10.1016/j.immuni.2007.10.010

67. Rosental B, Brusilovsky M, Hadad U, Oz D, Appel MY, Afergan F, et al. Proliferating cell nuclear antigen is a novel inhibitory ligand for the natural cytotoxicity receptor NKp44. J Immunol. (2011) 187:5693702. doi: 10.4049/jimmunol.1102267

68. Narni-Mancinelli E, Gauthier L, Baratin M, Guia S, Fenis A, Deghmane $\mathrm{AE}$, et al. Complement factor $\mathrm{P}$ is a ligand for the natural killer cell-activating receptor NKp46. Sci Immunol. (2017) 2:eaam9628. doi: 10.1126/sciimmunol.aam9628

69. Gaggero S, Bruschi M, Petretto A, Parodi M, Del Zotto G, Lavarello C, et al. Nidogen-1 is a novel extracellular ligand for the NKp44 activating receptor. Oncoimmunology. (2018) 7:e1470730. doi: 10.1080/2162402X.2018.1470730
70. Barrow AD, Edeling MA, Trifonov V, Luo J, Goyal P, Bohl B, et al. Natural killer cells control tumor growth by sensing a growth factor. Cell. (2018) 172:534-48.e19. doi: 10.1016/j.cell.2017.11.037

71. Fehniger TA, Shah MH, Turner MJ, VanDeusen JB, Whitman SP, Cooper MA, et al. Differential cytokine and chemokine gene expression by human NK cells following activation with IL-18 or IL-15 in combination with IL-12: implications for the innate immune response. J Immunol. (1999) 162:4511-20.

72. Cooper MA, Fehniger TA, Caligiuri MA. The biology of human natural killer-cell subsets. Trends Immunol. (2001) 22:633-40. doi: 10.1016/S1471-4906(01)02060-9

73. Ferlazzo G, Tsang ML, Moretta L, Melioli G, Steinman RM, Munz C. Human dendritic cells activate resting natural killer (NK) cells and are recognized via the NKp30 receptor by activated NK cells. J Exp Med. (2002) 195:343-51. doi: 10.1084/jem.20011149

74. Gerosa F, Baldani-Guerra B, Nisii C, Marchesini V, Carra G, Trinchieri G. Reciprocal activating interaction between natural killer cells and dendritic cells. J Exp Med. (2002) 195:327-33. doi: 10.1084/jem.20010938

75. Piccioli D, Sbrana S, Melandri E, Valiante NM. Contact-dependent stimulation and inhibition of dendritic cells by natural killer cells. J Exp Med. (2002) 195:335-41. doi: 10.1084/jem.20010934

76. Moretta A. Natural killer cells and dendritic cells: rendezvous in abused tissues. Nat Rev Immunol. (2002) 2:957-64. doi: 10.1038/nri956

77. Bellora F, Castriconi R, Dondero A, Reggiardo G, Moretta L, Mantovani A, et al. The interaction of human natural killer cells with either unpolarized or polarized macrophages results in different functional outcomes. Proc Natl Acad Sci U S A. (2010) 107:21659-64. doi: 10.1073/pnas.1007654108

78. Thoren FB, Riise RE, Ousback J, Della Chiesa M, Alsterholm M, Marcenaro E, et al. Human NK Cells induce neutrophil apoptosis via an NKp46- and Fas-dependent mechanism. J Immunol. (2012) 188:166874. doi: 10.4049/jimmunol.1102002

79. Pesce S, Thoren FB, Cantoni C, Prato C, Moretta L, Moretta A, et al. The innate immune cross talk between NK cells and eosinophils is regulated by the interaction of natural cytotoxicity receptors with eosinophil surface ligands. Front Immunol. (2017) 8:510. doi: 10.3389/fimmu.2017.00510

80. Martin-Fontecha A, Thomsen LL, Brett S, Gerard C, Lipp M, Lanzavecchia A, et al. Induced recruitment of $\mathrm{NK}$ cells to lymph nodes provides IFN-gamma for $\mathrm{T}(\mathrm{H}) 1$ priming. Nat Immunol. (2004) 5:1260-5. doi: 10.1038/ni1138

81. Ardolino M, Zingoni A, Cerboni C, Cecere F, Soriani A, Iannitto ML, et al. DNAM-1 ligand expression on Ag-stimulated T lymphocytes is mediated by ROS-dependent activation of DNAdamage response: relevance for NK-T cell interaction. Blood. (2011) 117:4778-86. doi: 10.1182/blood-2010-08-300954

82. Horowitz A, Strauss-Albee DM, Leipold M, Kubo J, Nemat-Gorgani N, Dogan OC, et al. Genetic and environmental determinants of human NK cell diversity revealed by mass cytometry. Sci Transl Med. (2013) 5:208ra145. doi: 10.1126/scitranslmed.3006702

83. Freud AG, Mundy-Bosse BL, Yu J, Caligiuri MA. The broad spectrum of human natural killer cell diversity. Immunity. (2017) 47:820-33. doi: 10.1016/j.immuni.2017.10.008

84. Nagler A, Lanier LL, Cwirla S, Phillips JH. Comparative studies of human FcRIII-positive and negative natural killer cells. J Immunol. (1989) 143:3183-91.

85. Cooper MA, Fehniger TA, Turner SC, Chen KS, Ghaheri BA, Ghayur $\mathrm{T}$, et al. Human natural killer cells: a unique innate immunoregulatory role for the CD56(bright) subset. Blood. (2001) 97:3146-51. doi: 10.1182/blood.V97.10.3146

86. Michel T, Poli A, Cuapio A, Briquemont B, Iserentant G, Ollert M, et al. Human CD56bright NK cells: an update. J Immunol. (2016) 196:292331. doi: 10.4049/jimmunol.1502570

87. Ferlazzo G, Thomas D, Lin SL, Goodman K, Morandi B, Muller WA, et al. The abundant NK cells in human secondary lymphoid tissues require activation to express killer cell Ig-like receptors and become cytolytic. J Immunol. (2004) 172:1455-62. doi: 10.4049/jimmunol.172. 3.1455

88. Romagnani C, Juelke K, Falco M, Morandi B, D’Agostino A, Costa R, et al. CD56brightCD16- killer Ig-like receptor- NK cells display longer telomeres 
and acquire features of CD56dim NK cells upon activation. J Immunol. (2007) 178:4947-55. doi: 10.4049/jimmunol.178.8.4947

89. Fauriat C, Long EO, Ljunggren HG, Bryceson YT. Regulation of human NKcell cytokine and chemokine production by target cell recognition. Blood. (2010) 115:2167-76. doi: 10.1182/blood-2009-08-238469

90. De Maria A, Bozzano F, Cantoni C, Moretta L. Revisiting human natural killer cell subset function revealed cytolytic CD56(dim)CD16+ NK cells as rapid producers of abundant IFN-gamma on activation. Proc Natl Acad Sci U S A. (2011) 108:728-32. doi: 10.1073/pnas.1012356108

91. Freud AG, Yokohama A, Becknell B, Lee MT, Mao HC, Ferketich AK, et al. Evidence for discrete stages of human natural killer cell differentiation in vivo. J Exp Med. (2006) 203:1033-43. doi: 10.1084/jem.20052507

92. Huntington ND, Vosshenrich CA, Di Santo JP. Developmental pathways that generate natural-killer-cell diversity in mice and humans. Nat Rev Immunol. (2007) 7:703-14. doi: 10.1038/nri2154

93. Lopez-Verges S, Milush JM, Pandey S, York VA, Arakawa-Hoyt J, Pircher $\mathrm{H}$, et al. CD57 defines a functionally distinct population of mature NK cells in the human CD56dimCD16+ NK-cell subset. Blood. (2010) 116:386574. doi: 10.1182/blood-2010-04-282301

94. Bjorkstrom NK, Riese P, Heuts F, Andersson S, Fauriat C, Ivarsson MA, et al. Expression patterns of NKG2A, KIR, and CD57 define a process of CD56dim NK-cell differentiation uncoupled from NK-cell education. Blood. (2010) 116:3853-64. doi: 10.1182/blood-2010-04-281675

95. Juelke K, Killig M, Luetke-Eversloh M, Parente E, Gruen J, Morandi B, et al. CD62L expression identifies a unique subset of polyfunctional CD56dim NK cells. Blood. (2010) 116:1299-307. doi: 10.1182/blood-2009-11-253286

96. Yu J, Freud AG, Caligiuri MA. Location and cellular stages of natural killer cell development. Trends Immunol. (2013) 34:573-82. doi: 10.1016/j.it.2013.07.005

97. Guma M, Angulo A, Vilches C, Gomez-Lozano N, Malats N, Lopez-Botet M. Imprint of human cytomegalovirus infection on the NK cell receptor repertoire. Blood. (2004) 104:3664-71. doi: 10.1182/blood-2004-05-2058

98. Schlums H, Cichocki F, Tesi B, Theorell J, Beziat V, Holmes TD, et al. Cytomegalovirus infection drives adaptive epigenetic diversification of NK cells with altered signaling and effector function. Immunity. (2015) 42:44356. doi: 10.1016/j.immuni.2015.02.008

99. Lee J, Zhang T, Hwang I, Kim A, Nitschke L, Kim M, et al. Epigenetic modification and antibody-dependent expansion of memory-like NK cells in human cytomegalovirus-infected individuals. Immunity. (2015) 42:43142. doi: 10.1016/j.immuni.2015.02.013

100. Cerwenka A, Lanier LL. Natural killer cell memory in infection, inflammation and cancer. Nat Rev Immunol. (2016) 16:11223. doi: 10.1038/nri.2015.9

101. Lopez-Verges S, Milush JM, Schwartz BS, Pando MJ, Jarjoura J, York VA, et al. Expansion of a unique $\mathrm{CD} 57^{+} \mathrm{NKG} 2 \mathrm{Chi}$ natural killer cell subset during acute human cytomegalovirus infection. Proc Natl Acad Sci U S A. (2011) 108:14725-32. doi: 10.1073/pnas. 1110900108

102. Lopez-Botet M, Muntasell A, Vilches C. The CD94/NKG2C+ NK-cell subset on the edge of innate and adaptive immunity to human cytomegalovirus infection. Semin Immunol. (2014) 26:145-51. doi: 10.1016/j.smim.2014.03.002

103. Della Chiesa M, Falco M, Bertaina A, Muccio L, Alicata C, Frassoni F, et al. Human cytomegalovirus infection promotes rapid maturation of NK cells expressing activating killer Ig-like receptor in patients transplanted with NKG2C-/- umbilical cord blood. J Immunol. (2014) 192:14719. doi: 10.4049/jimmunol.1302053

104. Sojka DK, Tian Z, Yokoyama WM. Tissue-resident natural killer cells and their potential diversity. Semin Immunol. (2014) 26:12731. doi: 10.1016/j.smim.2014.01.010

105. Bjorkstrom NK, Ljunggren HG, Michaelsson J. Emerging insights into natural killer cells in human peripheral tissues. Nat Rev Immunol. (2016) 16:310-20. doi: 10.1038/nri.2016.34

106. Lugli E, Hudspeth K, Roberto A, Mavilio D. Tissue-resident and memory properties of human T-cell and NK-cell subsets. Eur J Immunol. (2016) 46:1809-17. doi: 10.1002/eji.201545702

107. Melsen JE, Lugthart G, Lankester AC, Schilham MW. Human circulating and tissue-resident CD56(bright) natural killer cell populations. Front Immunol. (2016) 7:262. doi: 10.3389/fimmu.2016.00262
108. Peng H, Tian Z. Diversity of tissue-resident NK cells. Semin Immunol. (2017) 31:3-10. doi: 10.1016/j.smim.2017.07.006

109. Cibrian D, Sanchez-Madrid F. CD69: from activation marker to metabolic gatekeeper. Eur J Immunol. (2017) 47:946-53. doi: 10.1002/eji.201646837

110. Shiow LR, Rosen DB, Brdickova N, Xu Y, An J, Lanier LL, et al. CD69 acts downstream of interferon-alpha/beta to inhibit S1P1 and lymphocyte egress from lymphoid organs. Nature. (2006) 440:540-4. doi: 10.1038/nature04606

111. Walzer T, Chiossone L, Chaix J, Calver A, Carozzo C, Garrigue-Antar L, et al. Natural killer cell trafficking in vivo requires a dedicated sphingosine 1-phosphate receptor. Nat Immunol. (2007) 8:1337-44. doi: 10.1038/ni1523

112. Zhang N, Bevan MJ. Transforming growth factor-beta signaling controls the formation and maintenance of gut-resident memory $\mathrm{T}$ cells by regulating migration and retention. Immunity. (2013) 39:687-96. doi: 10.1016/j.immuni.2013.08.019

113. Campbell JJ, Qin S, Unutmaz D, Soler D, Murphy KE, Hodge MR, et al. Unique subpopulations of CD56+ NK and NK-T peripheral blood lymphocytes identified by chemokine receptor expression repertoire. $J$ Immunol. (2001) 166:6477-82. doi: 10.4049/jimmunol.166.11.6477

114. Arase H, Saito T, Phillips JH, Lanier LL. Cutting edge: the mouse NK cell-associated antigen recognized by DX5 monoclonal antibody is CD49b (alpha 2 integrin, very late antigen-2). J Immunol. (2001) 167:11414. doi: $10.4049 /$ jimmunol.167.3.1141

115. Raulet DH. Missing self recognition and self tolerance of natural killer (NK) cells. Semin Immunol. (2006) 18:145-50. doi: 10.1016/j.smim.2006.03.003

116. Hayakawa Y, Huntington ND, Nutt SL, Smyth MJ. Functional subsets of mouse natural killer cells. Immunol Rev. (2006) 214:47-55. doi: 10.1111/j.1600-065X.2006.00454.x

117. Yokoyama WM, Plougastel BF. Immune functions encoded by the natural killer gene complex. Nat Rev Immunol. (2003) 3:304-16. doi: $10.1038 /$ nri1055

118. Walzer T, Blery M, Chaix J, Fuseri N, Chasson L, Robbins SH, et al. Identification, activation, and selective in vivo ablation of mouse NK cells via NKp46. Proc Natl Acad Sci U S A. (2007) 104:33849. doi: 10.1073/pnas.0609692104

119. Sojka DK, Plougastel-Douglas B, Yang L, Pak-Wittel MA, Artyomov MN, Ivanova $Y$, et al. Tissue-resident natural killer (NK) cells are cell lineages distinct from thymic and conventional splenic NK cells. Elife. (2014) 3:e01659. doi: 10.7554/eLife.01659

120. Kim S, Iizuka K, Kang HS, Dokun A, French AR, Greco S, et al. In vivo developmental stages in murine natural killer cell maturation. Nat Immunol. (2002) 3:523-8. doi: 10.1038/ni796

121. Chiossone L, Chaix J, Fuseri N, Roth C, Vivier E, Walzer T. Maturation of mouse NK cells is a 4-stage developmental program. Blood. (2009) 113:548896. doi: 10.1182/blood-2008-10-187179

122. Crinier A, Milpied P, Escaliere B, Piperoglou C, Galluso J, Balsamo A, et al. High-dimensional single-cell analysis identifies organ-specific signatures and conserved NK cell subsets in humans and mice. Immunity. (2018) 49:971-86.e5. doi: 10.1016/j.immuni.2018.09.009

123. Yang C, Siebert JR, Burns R, Zheng Y, Mei A, Bonacci B, et al. Single-cell transcriptome reveals the novel role of T-bet in suppressing the immature NK gene signature. Elife. (2020) 9:e51339. doi: 10.7554/eLife.51339

124. Gasteiger G, Fan X, Dikiy S, Lee SY, Rudensky AY. Tissue residency of innate lymphoid cells in lymphoid and nonlymphoid organs. Science. (2015) 350:981-5. doi: 10.1126/science.aac9593

125. Simoni Y, Fehlings M, Kloverpris HN, McGovern N, Koo SL, Loh CY, et al. Human innate lymphoid cell subsets possess tissue-type based heterogeneity in phenotype and frequency. Immunity. (2017) 46:148161. doi: 10.1016/j.immuni.2016.11.005

126. Spits H, Bernink JH, Lanier L. NK cells and type 1 innate lymphoid cells: partners in host defense. Nat Immunol. (2016) 17:758-64. doi: 10.1038/ni.3482

127. Riggan L, Freud AG, O'Sullivan TE. True detective: unraveling group 1 innate lymphocyte heterogeneity. Trends Immunol. (2019) 40:90921. doi: 10.1016/j.it.2019.08.005

128. Fuchs A, Vermi W, Lee JS, Lonardi S, Gilfillan S, Newberry RD, et al. Intraepithelial type 1 innate lymphoid cells are a unique subset of IL12- and IL-15-responsive IFN-gamma-producing cells. Immunity. (2013) 38:769-81. doi: 10.1016/j.immuni.2013.02.010 
129. Bernink JH, Krabbendam L, Germar K, de Jong E, Gronke K, KofoedNielsen M, et al. Interleukin-12 and-23 control plasticity of $\mathrm{CD} 127^{+}$ group 1 and group 3 innate lymphoid cells in the intestinal lamina propria. Immunity. (2015) 43:146-60. doi: 10.1016/j.immuni.2015. 06.019

130. Cupedo T, Crellin NK, Papazian N, Rombouts EJ, Weijer K, Grogan JL, et al. Human fetal lymphoid tissue-inducer cells are interleukin 17-producing precursors to RORC+CD127+ natural killer-like cells. Nat Immunol. (2009) 10:66-74. doi: 10.1038/ni.1668

131. Killig $\mathrm{M}$, Glatzer $\mathrm{T}$, Romagnani $\mathrm{C}$. Recognition strategies of group 3 innate lymphoid cells. Front Immunol. (2014) 5:142. doi: $10.3389 /$ fimmu.2014.00142

132. Colonna M. Interleukin-22-producing natural killer cells and lymphoid tissue inducer-like cells in mucosal immunity. Immunity. (2009) 31:1523. doi: 10.1016/j.immuni.2009.06.008

133. Huang Q, Niu Z, Tan J, Yang J, Liu Y, Ma H, et al. IL-25 elicits innate lymphoid cells and multipotent progenitor type 2 cells that reduce renal ischemic/reperfusion injury. J Am Soc Nephrol. (2015) 26:2199211. doi: 10.1681/ASN.2014050479

134. Riedel JH, Becker M, Kopp K, Duster M, Brix SR, Meyer-Schwesinger C, et al. IL-33-Mediated expansion of type 2 innate lymphoid cells protects from progressive glomerulosclerosis. J Am Soc Nephrol. (2017) 28:206880. doi: 10.1681/ASN.2016080877

135. Cao Q, Wang Y, Niu Z, Wang C, Wang R, Zhang Z, et al. Potentiating tissue-resident type 2 innate lymphoid cells by IL-33 to prevent renal ischemia-reperfusion injury. J Am Soc Nephrol. (2018) 29:96176. doi: 10.1681/ASN.2017070774

136. Cameron GJM, Jiang SH, Loering S, Deshpande AV, Hansbro PM, Starkey MR. Emerging therapeutic potential of group 2 innate lymphoid cells in acute kidney injury. J Pathol. (2019) 248:9-15. doi: 10.1002/path.5242

137. Carrega P, Bonaccorsi I, Di Carlo E, Morandi B, Paul P, Rizzello $\mathrm{V}$, et al. CD56(bright)perforin(low) noncytotoxic human NK cells are abundant in both healthy and neoplastic solid tissues and recirculate to secondary lymphoid organs via afferent lymph. J Immunol. (2014) 192:380515. doi: 10.4049/jimmunol.1301889

138. Peng H, Jiang X, Chen Y, Sojka DK, Wei H, Gao X, et al. Liver-resident NK cells confer adaptive immunity in skin-contact inflammation. J Clin Invest. (2013) 123:1444-56. doi: 10.1172/JCI66381

139. Marquardt N, Beziat V, Nystrom S, Hengst J, Ivarsson MA, Kekalainen E, et al. Cutting edge: identification and characterization of human intrahepatic CD49a+ NK cells. J Immunol. (2015) 194:2467-71. doi: 10.4049/jimmunol.1402756

140. Hudspeth K, Donadon M, Cimino M, Pontarini E, Tentorio P, Preti M, et al. Human liver-resident CD56(bright)/CD16(neg) NK cells are retained within hepatic sinusoids via the engagement of CCR5 and CXCR6 pathways. J Autoimmun. (2016) 66:40-50. doi: 10.1016/j.jaut.2015.08.011

141. Stegmann KA, Robertson F, Hansi N, Gill U, Pallant C, Christophides T, et al. CXCR6 marks a novel subset of T-bet(lo)Eomes(hi) natural killer cells residing in human liver. Sci Rep. (2016) 6:26157. doi: 10.1038/srep26157

142. Cuff AO, Robertson FP, Stegmann KA, Pallett LJ, Maini MK, Davidson $\mathrm{BR}$, et al. Eomeshi NK cells in human liver are long-lived and do not recirculate but can be replenished from the circulation. J Immunol. (2016) 197:4283-91. doi: 10.4049/jimmunol.1601424

143. Harmon C, Robinson MW, Fahey R, Whelan S, Houlihan DD, Geoghegan J, et al. Tissue-resident Eomes(hi) T-bet(lo) CD56(bright) NK cells with reduced proinflammatory potential are enriched in the adult human liver. Eur J Immunol. (2016) 46:2111-20. doi: 10.1002/eji.201646559

144. Aw Yeang HX, Piersma SJ, Lin Y, Yang L, Malkova ON, Miner C, et al. Cutting edge: human CD49e- NK cells are tissue resident in the liver. $J$ Immunol. (2017) 198:1417-22. doi: 10.4049/jimmunol.1601818

145. Marquardt N, Kekalainen E, Chen P, Lourda M, Wilson JN, Scharenberg $\mathrm{M}$, et al. Unique transcriptional and protein-expression signature in human lung tissue-resident NK cells. Nat Commun. (2019) 10:3841. doi: 10.1038/s41467-019-11632-9

146. Cong J, Wei H. Natural killer cells in the lungs. Front Immunol. (2019) 10:1416. doi: 10.3389/fimmu.2019.01416

147. Hervier B, Russick J, Cremer I, Vieillard V. NK cells in the human lungs. Front Immunol. (2019) 10:1263. doi: 10.3389/fimmu.2019.01263
148. Koopman LA, Kopcow HD, Rybalov B, Boyson JE, Orange JS, Schatz $F$, et al. Human decidual natural killer cells are a unique NK cell subset with immunomodulatory potential. J Exp Med. (2003) 198:120112. doi: $10.1084 /$ jem. 20030305

149. Hanna J, Goldman-Wohl D, Hamani Y, Avraham I, Greenfield C, Natanson-Yaron S, et al. Decidual NK cells regulate key developmental processes at the human fetal-maternal interface. Nat Med. (2006) 12:106574. doi: $10.1038 / \mathrm{nm} 1452$

150. Vacca P, Moretta L, Moretta A, Mingari MC. Origin, phenotype and function of human natural killer cells in pregnancy. Trends Immunol. (2011) 32:51723. doi: 10.1016/j.it.2011.06.013

151. Moffett A, Colucci F. Uterine NK cells: active regulators at the maternal-fetal interface. J Clin Invest. (2014) 124:1872-9. doi: 10.1172/JCI68107

152. Tessmer MS, Reilly EC, Brossay L. Salivary gland NK cells are phenotypically and functionally unique. PLoS Pathog. (2011) 7:e1001254. doi: 10.1371/journal.ppat.1001254

153. Cortez VS, Fuchs A, Cella M, Gilfillan S, Colonna M. Cutting edge: salivary gland NK cells develop independently of Nfil3 in steady-state. J Immunol. (2014) 192:4487-91. doi: 10.4049/jimmunol.1303469

154. Wensveen FM, Jelencic V, Valentic S, Sestan M, Wensveen TT, Theurich $S$, et al. NK cells link obesity-induced adipose stress to inflammation and insulin resistance. Nat Immunol. (2015) 16:376-85. doi: 10.1038/ni.3120

155. Law BMP, Wilkinson R, Wang X, Kildey K, Lindner M, Rist MJ, et al. Interferon-gamma production by tubulointerstitial human CD56(bright) natural killer cells contributes to renal fibrosis and chronic kidney disease progression. Kidney Int. (2017) 92:79-88. doi: 10.1016/j.kint.2017.02.006

156. Turner JE, Becker M, Mittrucker HW, Panzer U. Tissueresident lymphocytes in the kidney. J Am Soc Nephrol. (2018) 29:389-99. doi: 10.1681/ASN.2017060599

157. Turner JE, Rickassel C, Healy H, Kassianos AJ. Natural killer cells in kidney health and disease. Front Immunol. (2019) 10:587. doi: 10.3389/fimmu.2019.00587

158. Victorino F, Sojka DK, Brodsky KS, McNamee EN, Masterson JC, Homann D, et al. Tissue-resident NK cells mediate ischemic kidney injury and are not depleted by anti-asialo-GM1 antibody. J Immunol. (2015) 195:497385. doi: 10.4049/jimmunol.1500651

159. Guia S, Narni-Mancinelli E. Helper-like innate lymphoid cells in humans and mice. Trends Immunol. (2020) 41:436-52. doi: 10.1016/j.it.2020.03.002

160. Weizman OE, Adams NM, Schuster IS, Krishna C, Pritykin Y, Lau C, et al. ILC1 confer early host protection at initial sites of viral infection. Cell. (2017) 171:795-808.e12. doi: 10.1016/j.cell.2017.09.052

161. Wee YM, Go H, Choi MY, Jung HR, Cho YM, Kim YH, et al. Tissue-resident natural killer cells exacerbate tubulointerstitial fibrosis by activating transglutaminase 2 and syndecan-4 in a model of aristolochic acid-induced nephropathy. BMB Rep. (2019) 52:554-9. doi: 10.5483/BMBRep.2019.52.9.193

162. Gomez H, Ince C, De Backer D, Pickkers P, Payen D, Hotchkiss J, et al. A unified theory of sepsis-induced acute kidney injury: inflammation, microcirculatory dysfunction, bioenergetics, and the tubular cell adaptation to injury. Shock. (2014) 41:3-11. doi: 10.1097/SHK.0000000000000052

163. Radi ZA. Immunopathogenesis of acute kidney injury. Toxicol Pathol. (2018) 46:930-43. doi: 10.1177/0192623318799976

164. Moore PK, Hsu RK, Liu KD. Management of acute kidney injury: core curriculum 2018. Am J Kidney Dis. (2018) 72:13648. doi: 10.1053 /j.ajkd.2017.11.021

165. Zhang B, Ramesh G, Uematsu S, Akira S, Reeves WB. TLR4 signaling mediates inflammation and tissue injury in nephrotoxicity. J Am Soc Nephrol. (2008) 19:923-32. doi: 10.1681/ASN.2007090982

166. Pulskens WP, Teske GJ, Butter LM, Roelofs JJ, van der Poll T, Florquin $\mathrm{S}$, et al. Toll-like receptor-4 coordinates the innate immune response of the kidney to renal ischemia/reperfusion injury. PLOS ONE. (2008) 3:e3596. doi: 10.1371/journal.pone.0003596

167. Tsuboi N, Yoshikai Y, Matsuo S, Kikuchi T, Iwami K, Nagai Y, et al. Roles of toll-like receptors in C-C chemokine production by renal tubular epithelial cells. J Immunol. (2002) 169:2026-33. doi: 10.4049/jimmunol.169.4.2026

168. Shigeoka AA, Holscher TD, King AJ, Hall FW, Kiosses WB, Tobias PS, et al. TLR2 is constitutively expressed within the kidney and participates in ischemic renal injury through both 
MyD88-dependent and -independent pathways. J Immunol. (2007) 178:6252-8. doi: 10.4049/jimmunol.178.10.6252

169. Kim HJ, Lee JS, Kim A, Koo S, Cha HJ, Han JA, et al. TLR2 signaling in tubular epithelial cells regulates NK cell recruitment in kidney ischemia-reperfusion injury. J Immunol. (2013) 191:2657-64. doi: 10.4049/jimmunol.1300358

170. Ascon DB, Lopez-Briones S, Liu M, Ascon M, Savransky V, Colvin RB, et al. Phenotypic and functional characterization of kidney-infiltrating lymphocytes in renal ischemia reperfusion injury. J Immunol. (2006) 177:3380-7. doi: 10.4049/jimmunol.177.5.3380

171. Feng L, Cheng F, Ye Z, Li S, He Y, Yao X, et al. The effect of renal ischemia-reperfusion injury on expression of RAE-1 and H60 in mice kidney. Transplant Proc. (2006) 38:2195-8. doi: 10.1016/j.transproceed.2006.06.013

172. Zhang ZX, Wang S, Huang $X$, Min WP, Sun H, Liu W, et al. NK cells induce apoptosis in tubular epithelial cells and contribute to renal ischemia-reperfusion injury. J Immunol. (2008) 181:748998. doi: 10.4049/jimmunol.181.11.7489

173. Chen GE, Wu H, Ma J, Chadban SJ, Sharland A. Toll-like receptor 4 engagement contributes to expression of NKG2D ligands by renal tubular epithelial cells. Nephrol Dial Transplant. (2011) 26:3873-81. doi: 10.1093/ndt/gfr234

174. Wu H, Ma J, Wang P, Corpuz TM, Panchapakesan U, Wyburn KR, et al. HMGB1 contributes to kidney ischemia reperfusion injury. J Am Soc Nephrol. (2010) 21:1878-90. doi: 10.1681/ASN.2009101048

175. Luo L, Lu J, Wei L, Long D, Guo JY, Shan J, et al. The role of HIF1 in up-regulating MICA expression on human renal proximal tubular epithelial cells during hypoxia/reoxygenation. BMC Cell Biol. (2010) 11:91. doi: 10.1186/1471-2121-11-91

176. Basile DP, Rovak JM, Martin DR, Hammerman MR. Increased transforming growth factor-beta 1 expression in regenerating rat renal tubules following ischemic injury. Am J Physiol. (1996) 270:F500-9. doi: 10.1152/ajprenal.1996.270.3.F500

177. Song H, Kim Y, Park G, Kim YS, Kim S, Lee HK, et al. Transforming growth factor-betal regulates human renal proximal tubular epithelial cell susceptibility to natural killer cells via modulation of the NKG2D ligands. Int J Mol Med. (2015) 36:1180-8. doi: 10.3892/ijmm. 2015.2317

178. Guan Q, Nguan CY, Du C. Expression of transforming growth factor-beta1 limits renal ischemia-reperfusion injury. Transplantation. (2010) 89:13207. doi: 10.1097/TP.0b013e3181d8e9dc

179. Salih HR, Rammensee HG, Steinle A. Cutting edge: down-regulation of MICA on human tumors by proteolytic shedding. J Immunol. (2002) 169:4098-102. doi: 10.4049/jimmunol.169.8.4098

180. Castriconi R, Cantoni C, Della Chiesa M, Vitale M, Marcenaro E, Conte R, et al. Transforming growth factor beta 1 inhibits expression of NKp30 and NKG2D receptors: consequences for the NK-mediated killing of dendritic cells. Proc Natl Acad Sci USA. (2003) 100:41205. doi: 10.1073/pnas.0730640100

181. Lee JC, Lee KM, Kim DW, Heo DS. Elevated TGF-beta1 secretion and down-modulation of NKG2D underlies impaired NK cytotoxicity in cancer patients. J Immunol. (2004) 172:733540. doi: 10.4049/jimmunol.172.12.7335

182. Patarca R, Freeman GJ, Singh RP, Wei FY, Durfee T, Blattner F, et al. Structural and functional studies of the early $\mathrm{T}$ lymphocyte activation 1 (Eta-1) gene. Definition of a novel $\mathrm{T}$ cell-dependentresponse associated with genetic resistance to bacterial infection. J Exp Med. (1989) 170:14561. doi: 10.1084/jem.170.1.145

183. Pollack SB, Linnemeyer PA, Gill S. Induction of osteopontin mRNA expression during activation of murine NK cells. J Leukoc Biol. (1994) 55:398-400. doi: 10.1002/jlb.55.3.398

184. Ashkar S, Weber GF, Panoutsakopoulou V, Sanchirico ME, Jansson M, Zawaideh S, et al. Eta-1 (osteopontin): an early component of type-1 (cell-mediated) immunity. Science. (2000) 287:860-4. doi: 10.1126/science.287.5454.860

185. Xie Y, Sakatsume M, Nishi S, Narita I, Arakawa M, Gejyo F. Expression, roles, receptors, and regulation of osteopontin in the kidney. Kidney Int. (2001) 60:1645-57. doi: 10.1046/j.1523-1755.2001.00032.x

186. Persy VP, Verhulst A, Ysebaert DK, De Greef KE, De Broe ME. Reduced postischemic macrophage infiltration and interstitial fibrosis in osteopontin knockout mice. Kidney Int. (2003) 63:543-53. doi: 10.1046/j.1523-1755.2003.00767.x

187. Zhang ZX, Shek K, Wang S, Huang X, Lau A, Yin Z, et al. Osteopontin expressed in tubular epithelial cells regulates NK cellmediated kidney ischemia reperfusion injury. J Immunol. (2010) 185:96773. doi: 10.4049/jimmunol.0903245

188. Noiri E, Dickman K, Miller F, Romanov G, Romanov VI, Shaw R, et al. Reduced tolerance to acute renal ischemia in mice with a targeted disruption of the osteopontin gene. Kidney Int. (1999) 56:7482. doi: 10.1046/j.1523-1755.1999.00526.x

189. Cen C, Aziz M, Yang WL, Nicastro JM, Coppa GF, Wang P. Osteopontin blockade attenuates renal injury after ischemia reperfusion by inhibiting NK cell infiltration. Shock. (2017) 47:52-60. doi: 10.1097/SHK.0000000000000721

190. Zhang ZX, Huang X, Jiang J, Lau A, Yin Z, Liu W, et al. Natural killer cells mediate long-term kidney allograft injury. Transplantation. (2015) 99:916-24. doi: 10.1097/TP.0000000000000665

191. Kim HJ, Lee JS, Kim JD, Cha HJ, Kim A, Lee SK, et al. Reverse signaling through the costimulatory ligand CD137L in epithelial cells is essential for natural killer cell-mediated acute tissue inflammation. Proc Natl Acad Sci U S A. (2012) 109:E13-22. doi: 10.1073/pnas.1112256109

192. Du C, Wang S, Diao H, Guan Q, Zhong R, Jevnikar AM. Increasing resistance of tubular epithelial cells to apoptosis by shRNA therapy ameliorates renal ischemia-reperfusion injury. Am J Transplant. (2006) 6:2256-67. doi: 10.1111/j.1600-6143.2006.01478.x

193. Demmers MW, Korevaar SS, Betjes MG, Weimar W, Rowshani AT, Baan CC. Limited efficacy of immunosuppressive drugs on CD8+ T cell-mediated and natural killer cell-mediated lysis of human renal tubular epithelial cells. Transplantation. (2014) 97:1110-8. doi: 10.1097/TP.0000000000000108

Conflict of Interest: The authors declare that the research was conducted in the absence of any commercial or financial relationships that could be construed as a potential conflict of interest.

Copyright (c) 2020 Cantoni, Granata, Bruschi, Spaggiari, Candiano and Zaza. This is an open-access article distributed under the terms of the Creative Commons Attribution License (CC BY). The use, distribution or reproduction in other forums is permitted, provided the original author(s) and the copyright owner(s) are credited and that the original publication in this journal is cited, in accordance with accepted academic practice. No use, distribution or reproduction is permitted which does not comply with these terms. 